\title{
MODEL KAJI TINDAK PROGRAM PEMBANGUNAN PARTISIPATIF PENGENTASAN KEMISKINAN DAN RAWAN PANGAN
}

\author{
P. Eko Prasetyo ${ }^{1}$, Marimin ${ }^{1}$, dan Adang Samsudin S. ${ }^{2}$ \\ ${ }^{1}$ Fakultas Ekonomi Universitas Negeri Semarang \\ ${ }^{2}$ Fakultas Ilmu Sosial Universitas Negeri Semarang \\ Gedung C Kampus Sekaran Gunungpati, Semarang, Indonesia Telepon +62-24-8508015
}

Diterima 2 September 2010/Disetujui 5 Nopember 2010

\begin{abstract}
The objective of the article was to explain essential and urgency of the model of participative development program as an effort to maximize real potencies: economy, social, politic and local culture, so that they can meet living need themselves independently and sustainability. The subjects of the study are all local poor people in Bringin rural area. Result of the research indicated that people awareness can maximize their potency that determined by the creativity and not due to the facility as government gave. The research explained that the incapable people problem was not merely due to absence of capital. However, it was due to awareness and working ethos that awakening in order to resolve the poverty problem. Therefore, in the evaluative action at least it was required four pillars, namely: job opportunity, social protection, capability improvement and people-empowering pillars. Then, evaluative action implementation of widening empowerment program based on local resource and creative economy was an essential, urgent strategy model to develop as effort of resolving poverty.
\end{abstract}

Keywords: evaluative action, participative, empowerment, local potency, creative economy

\begin{abstract}
Abstrak: Tujuan artikel ini untuk menjelaskan esensi dan urgensi model kaji tindak program pembangunan partisipatif sebagai upaya memaksimalkan potensi riil; ekonomi, sosial, politik dan budaya warga masyarakat miskin setempat, sehingga mereka dapat memenuhi kebutuhan hidupnya secara mandiri dan berkelanjutan. Subyek dalam penelitian ini seluruh warga miskin di Kecamatan Bringin. Hasil penelitian menunjukkan bahwa kesadaran masyarakat mampu memaksimalkan potensinya sendiri lebih ditentukan oleh kreatifitasnya dan bukan karena fasilitas yang diberikan oleh pemerintah. Hasil penelitian menjelaskan bahwa masalah ketidakberdayaan masyarakat tidak selamanya disebabkan karena ketiadaan modal namun dikarenakan kesadaran dan etos kerja yang belum terbangkitkan untuk keluar masalah kemiskinan. Dalam kaji tindak ini paling tidak diperlukan empat pilar yakni; penciptaan kesempatan kerja dan berusaha, perlindungan sosial, peningkatan kemampuan dan pilar pemberdayaan masyarakat. Selanjutnya, implementasi kaji tindak perluasan program pemberdayaan berbasis potensi sumber daya lokal dan ekonomi kreatif adalah salah satu model strategi yang esensi dan urgensi untuk dikembangkan sebagai upaya pengentasan kemiskinan.
\end{abstract}

Kata kunci: kaji tindak, partisipatif, pemberdayaan, potensi lokal, dan ekonomi kreatif

\section{PENDAHULUAN}

Model program pembangunan berbasis pada keterlibatan seluruh komponen atau potensi masyarakat lokal setempat merupakan model pembangunan berkelanjutan yang saat ini ba- nyak dikembangkan. Perluasan program ini berarti memberikan penguatan peran serta warga masyarakat setempat untuk lebih mampu mengoptimalkan seluruh potensi sumber daya yang ada secara produktif, kreatif dan berwawasan ke depan untuk pengentasan kemiskinan 
dan rawan pangan secara mandiri. Karena itu, model kaji tindak perluasan program ini harus didukung dengan tiga hal pokok, yakni; kearifan lokal yang produktif, institusi terkait, dan kreatifitas individu atau kelompok inovatif.

Latar belakang penulisan artikel hasil penelitian ini sesuai dengan Rencana Kerja Pemerintahan (RKP) Presiden SBY pada KIB I dan KIB II yang difokuskan pada triple track strategy yakni; (pro growth, pro poor dan pro job) atau peningkatan pertumbuhan ekonomi untuk mengurangi kemiskinan dan pengangguran. Dalam kaitannya dengan hal tersebut, berbagai kajian menyatakan bahwa pertumbuhan ekonomi Indonesia masih rendah dan tidak berkualitas, sehingga tidak banyak manfaatnya untuk mengurangi masalah; kemiskinan, pengangguran dan ketimpangan distribusi pendapatan. Argumentasinya adalah; karena pertumbuhan ekonomi Indonesia tidak sepenuhnya bertumpu pada kekuatan dan potensi domestik, serta sangat rentan terhadap gejolak eksternal. Karena itu, perlu diciptakan iklim perekonomian yang mendorong masyarakat untuk tidak hanya cenderung membeli, namun juga mampu untuk membuat produk sendiri yang berbasis domestik.

Secara teori sosial-ekonomi, masalah kemiskinan terjadi tidak begitu saja, melainkan ada sebab-akibat. Para akademisi umumnya lebih suka mempelajari kemiskinan dari sisi sebab-sebab kemiskinan, terutama kemiskinan struktural. Namun demikian, kita tetap harus memahami apa yang dimaksud kemiskinan itu sendiri. mengapa masalah kemiskinan hingga saat ini masih merupakan salah satu problem sosial-ekonomi yang amat serius. Karena itu, sebelum bertidak, perlu diidentifikasikan terlebih dahulu dengan cermat apa sebenarnya yang dimaksud kemiskinan itu sendiri, mengapa sebenarnya kemiskinan itu terjadi, bagaimana cara mengukurnya serta bagaimana cara mengatasinya.

Bagi kelompok pengambil kebijakan, yang diperlukan adalah profil miskin. Mereka lebih membutuhkan ukuran "garis kemiskinan" untuk mengukur kemiskinan itu sendiri. Oleh sebab itu, kemiskinan dapat dibedakan menjadi tiga pengertian: kemiskinan absolut, kemiskinan relatif dan kemiskinan kultural. Konsep mis- kin dalam artikel penelitian ini dapat diartikan sebagai posisi relatifnya, dan bukan hanya miskin absolut, karena pendapatan mereka juga meningkat, namun posisi relatifnya tidak berubah.

Seseorang termasuk golongan miskin absolut jika hasil pendapatannya berada di bawah garis kemiskinan, tidak cukup untuk memenuhi kebutuhan hidup minimum: pangan, sandang, kesehatan, papan, pendidikan. Seseorang yang tergolong miskin relatif sebenarnya telah hidup di atas garis kemiskinan, namun masih berada di bawah kemampuan masyarakat sekitarnya. Sedang miskin kultural berkaitan erat dengan sikap seseorang atau sekelompok masyarakat yang tidak mau berusaha memperbaiki tingkat kehidupannya sekalipun ada usaha dari pihak lain yang membantunya. Kemiskinan kultural terjadi sebagai akibat dari adanya budaya masyarakat dan etos kerja yang lemah. Sedangkan, kemiskinan struktural terjadi karena adanya struktur kebijakan pemerintah yang timpang sebagai akibat dari telah terjadinya ketidakadilan pada kehidupan masyarakat dalam waktu yang cukup lama.

Selanjutnya, kemiskinan itu sendiri dapat dilihat dari berbagai dimensi. Kemiskinan yang disebabkan berkaitan dengan pembangunan dapat dibedakan pula menjadi kemiskinan subsisten (kemiskinan sebagai akibat dari rendahnya pembangunan), kemiskinan pedesaan (kemiskinan sebagai akibat peminggiran pedesaan dalam proses pembangunan), kemiskinan perkotaan (kemiskinan yang disebabkan oleh hakekat dan percepatan pertumbuhan perkotaan), kemiskinan sosial (kemiskinan yang dialami oleh para perempuan, anak-anak, dan kelompok minoritas. Kemiskinan konsekuensial, yaitu kemiskinan yang terjadi akibat kejadian-kejadian lain atau faktor-faktor eksternal di luar si miskin, seperti; konflik, bencana alam, kerusakan lingkungan dan tingginya laju jumlah penduduk melebihi laju jumlah pendapatan nasional. Apabila kita telusuri lebih lanjut dari sebab dan akibatnya maka, dapat ditegaskan bahwa mereka miskin memang karena ia miskin. Logika berpikir secara makro ini sebenarnya telah lama dikemukakan oleh Ragnar Nurkse, seorang ahli ekonomi pembangunan di tahun 1953, yakni; (a poor country is poor because it is 
poor).

Selain itu, penyebab kemiskinan yang bermuara pada lingkaran setan kemiskinan (vicious circle of poverty) tersebut juga telah diidentifikasikan oleh; Ansel M. Sharp dkk (1996). Ia mengidentifikasikan tiga penyebab kemiskinan yang dipandang dari sisi ekonomi. Pertama, secara mikro, kemiskinan terjadi karena adanya ketidaksamaan pola kepemilikan sumber daya yang menimbulkan distribusi pendapatan timpang. Penduduk miskin hanya memiliki sumber daya yang terbatas dan kualitasnya rendah. Kedua, kemiskinan terjadi sebagai akibat perbedaan kualitas sumber daya manusia (SDM). Kualitas SDM yang rendah berbarti produktivitas rendah, dan pada gilirannya upah atau pendapatannya rendah. Rendahnya kualitas SDM ini terjadi karena rendahnya tingkat pendidikan, nasib yang kurang beruntung, adanya diskriminasi, atau keturunan. Ketiga, kemiskinan terjadi sebagai akibat perbedaan akses dalam kepemilikan modal.

Dalam artikel penelitian ini, batasan pengertian kemiskinan secara operasional cenderung digunakan pendekatan kemiskinan dari UU No. 5 tahun 2000 tentang program pengentasan kemiskinan nasional (PPKN). Sedangkan, ukuran garis kemiskinan secara makro digunakan metode pendekatan BPS. Dengan demikian, upaya-upaya tindakan strategi sebagai solusi untuk pengentasan kemiskinan dalam penelitian ini cenderung digunakan model strategi yang lebih mampu mengurangi jumlah orang miskin yang dapat diukur dari tiga dimensi kebutuhan pokok, kebutuhan sosial, dan kebijakan pembangunan.

Penelitian sebelumnya tentang hubungan antara pertumbuhan ekonomi, kemiskinan, dan ketimpangan telah banyak dilakukan di Indonesia, salah satunya dilakukan oleh Sumarto (2002, 2004) dari SMERU Research Institute. Berbagai hasil penelitian menunjukkan bahwa kemiskinan berhubungan erat dengan pertumbuhan ekonomi yang rendah dan tidak berkualitas, sehingga hubungan erat ini menjadi tema sentral oleh Pemerintah Indonesia, yakni seperti yang tertuang dalam RKP sejak tahun 2004-2009 hingga mendatang. Dalam RKP tersebut telah ditegaskan bahwa konsentrasi kerja Pemerintahan SBY difokuskan untuk memacu pertumbuhan ekonomi yang tinggi untuk mengurangi kemiskinan dan pengangguran (pro growth, pro job dan pro poor).

Berbagai penelitian lain, (Prasetyo, 2008) menunjukkan bahwa pertumbuhan ekonomi tidak hanya dihasilkan oleh penambahan investasi stok modal dan jumlah tenaga kerja, tetapi juga oleh peningkatan produktivitas faktor-faktor produksi akibat perubahan teknologi dan peningkatan kualitas SDM. Dengan demikian, investasi untuk meningkatkan SDM yang berkualitas mutlak diperlukan. Jika modal SDM (human capital) sebagai cerminan manusia dalam masyarakat dan sumber daya sosial (social capital) itu baik dan berkualitas, maka kedua modal ini merupakan sumber kekuatan utama yang dihasilkan manusia dalam kehidupan bermasyarakat. Artinya, dalam meningkatkan pertumbuhan ekonomi yang baik dan berkualitas sebagai syarat cukup dalam pembangunan ekonomi, sudah pasti dibutuhkan modal pendidikan untuk warga atau pemberdayaan masyarakat. Menurut kaidah ekonomi, pemberdayaan warga masyarakat adalah proses perolehan pelaku ekonomi untuk mendapatkan surplus value sebagai hak asasi manusia yang terlibat dalam kegiatan produksi. Upaya ini dapat dilakukan melalui distribusi penguasaan faktor-faktor produksi (melalui kebijakan politik ekonomi yang tepat dengan kondisi dan tingkatan sosial budaya masyarakat setempat).

Tujuan penulisan artikel hasil penelitian ini adalah agar dapat dikenalinya model dasar strategi pengentasan kemsikinan yang kredibel dan akuntabel serta mudah dan murah dilakukan sendiri oleh warga miskin khalayak sasaran secara mandiri dan berkelanjutan, baik bertaraf lokal maupun nasional. Karena itu, dalam artikel ini peneliti berusaha untuk menjelaskan dan menganalisis dasar-dasar atau langkahlangkah perbaikan bagi suatu aspek kehidupan yang dipandang perlu diperbaiki yakni model strategi pengentasan kemiskinan. Untuk itu, tim peneliti berusaha menjelaskan berbagai kebaikan dan keburukan serta kekurangannya di dalam aspek tersebut yang diselidiki dapat digunakan sebagai upaya pengentasan kemiskinan. Selanjutnya, dirumuskan dan dijelaskan alternatif-alternatif cara yang terbaik untuk melakukan langkah-langkah kebijakan yang 
tepat dalam mengatasi masalah kemiskinan tersebut.

\section{METODE PENELITIAN}

Penelitian ini didesain dengan model pendekatan kualitatif yang dilatarbelakangi dari pendekatan kuantitatif dari penelitian sebelumnya dan program pemerintah. Oleh karena itu, artikel hasil penelitian ini lebih menjelaskan pemahaman terhadap pokok masalah yang diteliti yakni masalah kemiskinan dan rawan pangan. Subyek dalam penelitian ini adalah seluruh warga miskin di Kecamatan Bringin, Kabupaten Semarang. Agar diperoleh data yang mendalam, diambilkan enam desa dan tujuh informan pokok. Pengumpulan data terutama dilakukan dengan observasi, partisipasi, wawancara terstruktur yang mendalam, serta angket. Meskipun demikian, agar diperoleh diskripsi secara menyeluruh tentang kemiskinan warga masyarakat tersebut, juga dilakukan wawancara dan angket terhadap 126 rumah tangga miskin dan rawan pangan sebagai responden yang dianggap respresentatif.

Untuk kepentingan analisis, digunakan variabel tingkat kemiskinan sebagai variabel utama dan sebab-sebab terjadinya kemiskinan serta cara mengatasisnya, dan beberapa variabel tingkat produksi serta variabel faktor produksi dari setiap usaha yang ditekuninya. Teknik analisis diawali dari data sebab-sebab mengapa terjadi kemiskinan di daerah tersebut, selanjutnya dikaji lebih dalam potensi ekonomi lokal setempat yang produktif, inovatif dan kreatif yang dapat dikembangkan oleh warga miskin di wilayah desa tersebut. Variabel kontrolnya adalah potensi warga, kearifan lokal serta ekonomi kreatif.

\section{HASIL DAN PEMBAHASAN}

\section{Kondisi Umum Daerah Penelitian}

Secara topografis, daerah penelitian ini merupakan salah satu wilayah kecamatan yang terletak di lereng perbukitan dengan curah hujan yang rendah yakni \pm 94 hari hujan dalam setahun. Ketinggian air dari permukaan air laut $\pm 330 \mathrm{~m}$, belum ada irigasi yang baik, dan kedalaman air sumur rata-rata \pm 25 meter, sehingga wilayah ini merupakan salah satu dari lima kecamatan yang sering terancam kekeringan. Lima wilayah yang sering teracam kekeringan di musim kemarau di Kabupaten Semarang adalah; Bringin, Bancak, Pringapus, Bawen dan Pabelan. Namun, Bringin dan Brancak tergolong yang paling parah.

Air adalah salah satu sumber penting kehidupan. Di wilayah ini air merupakan salah satu kendala utama kehidupan. Sebagian besar jenis pengairan diperoleh dari pengairan tadah hujan, dan hanya sedikit yang dari irigasi teknis dan setengah teknis. Ketika curah hujan kurang, dan air bersih dari sumur untuk kebutuhan rumah tangga saja kurang, apalagi air untuk tanaman dan hewan. Padahal, daerah ini juga belum ada irigasi yang baik. Dengan demikian, kondisi rawan pangan dan kemiskinan yang terjadi di wilayah peneitian ini banyak dipengaruhi oleh kondisi alam dan lingkungannya.

Berdasarkan data Kecamatan Dalam Angka dan data BPS (2007-2009), wilayah Kecamatan Bringin adalah sebagai salah satu daerah yang mengalami defisit status pangan terbesar, bersamaan dengan dua wilayah daerah kecamatan lain yakni; Kecamatan Bancak dan Kecamatan Ungaran Barat. Selain itu, daerah ini juga merupakan salah satu wilayah yang terdapat banyak jumlah warga miskinnya, terutama di beberapa desa yakni; Bringin, Truko, Wiru, Gogodalem, Rembes dan Sambirejo. Dari sejumlah 16 desa yang ada, jumlah warga miskin di desa tersebut lebih dari 500 warga, sehingga kegiatan kajian penelitian ini lebih banyak dipusatkan di wilayah daerah tersebut.

Berdasarkan data Kecamatan Bringin dalam angka tahun (2005, 2006, 2007, dan 2008), dapat ditegaskan bahwa daerah ini merupakan salah satu wilayah daerah yang tergolong lambat dalam perkembangan pembangunannya. Khususnya proses pembangunan ekonomi, hampir tidak banyak kemajuan yang berarti. Jumlah sarana perekonomian seperti; pasar, koperasi, KUD, bank, wartel, toko atau warung masih sangat minim sekali. Luas wilayah daerah Kecamatan Bringin sebesar $61,89 \mathrm{Km}^{2}$, dengan jumlah penduduk sebesar 43.987 jiwa, dan 
jumlah keluarga sebanyak 12.982 KK, serta tingkat kepadatan penduduk per jiwa $/ \mathrm{km}^{2}$ sebesar 713, dan tingkat kepadatan keluarga sebesar 210 per KK.

Luas tanah di wilayah tersebut sebagian besar digunakan untuk tanah sawah, tanah ladang, tanah pekarangan, dan hutan negara. Selanjutnya, luas tanah tersebut sebagian besar ditanami padi sawah, jagung, kacang tanah, kedelai dan umbi-umbian yakni ubi jalar dan ubi kayu. Luas tanah yang digunakan untuk tanaman padi sawah, seluas 4.062 ha dengan tingkat produksi 17.615 ton, dan rata-rata produksi/ha sebanyak 43,37 kwintal. Sedangkan, luas panen jagung sebesar $1.181 \mathrm{ha}$, tingkat produksi 3.463 ton dengan rata-rata produksi/ha sebesar 29,32 kwintal. Sementara itu, penggunaan luas tanah untuk hasil produksi yang lainnya seperti kacang tanah, umbi-umbian dan kedelai, lebih kecil daripada padi sawah dan jagung tersebut.

Mata pencaharian sebagian besar penduduk di wilayah ini adalah sebagai petani, buruh tani, buruh bangunan dan buruh industri. Dari sejumlah total 25.435 jiwa yang memiliki mata pencahrian, sebesar 6.879 sebagai petani, 6.773 sebagai buruh tani, 2.459 sebagai buruh bangunan, 2.098 sebagai buruh industri, 761 PNS/ ABRI, 745 pedagang, 208 pengusaha kecil, 201 angkutan, dan sebesar 4.822 lainnya seperti sebagai pekerja srabutan, dan 489 pensiunan. Selain itu, tingkat pendidikan warga di wilayah daerah ini tergolong masih rendah. Sebagian besar tidak tamat SD yakni sebesar 8.225, tamat SD sebesar 11.234, tamat SLTP sebanyak 5.129, dan tamat SLTA sebanyak 3.808. Sedangkan, yang berpendidikan tinggi masih sangat sedikit sekali, yakni tamat setingkat diploma sebesar 1.236 dan tamat sarjana ke atas hanya sebanyak 800 orang.

Keberadaan industri kecil rumah tangga di wilayah daerah penelitian ini masih tergolong sangat kecil, dan tidak ada industri menengah atau besar. Sebagian besar industri kecil rumah tangga ini merupakan industri anyaman bambu sebanyak 1.557 unit usaha, mebel 98 unit usaha, tempe/tahu sebesar 85 unit usaha, gula kelapa 37 unit usaha, dan lainnya 237 unit usaha. Semua unit usaha ini sebenarnya masih sangat potensial untuk dikembangkan sebagai upaya pengentasan kemiskinan di wilayah daerah penelitian ini.

\section{Kemiskinan dan Kesejahteraan Masyarakat di Pedesaan}

Memahami kesejahteraan dan masalah kemiskinan merupakan langkah pertama yang harus dipahami dalam pengentasan kemiskinan. Berkurangnya kemiskinan berarti meningkatkan kesejahteraan. Kedua konsep istilah tersebut saling terkait dan merupakan dua sisi yang berbeda atas masalah yang sama. Adanya kemiskinan pada dasarnya adalah kurangnya kesejahteraan. Karena itu, kedua istilah tersebut dalam artikel penelitian ini sering digunakan bergantian dan tak perlu diperdebatkan. Batasan pengertian kedua konsep tersebut ditujukan untuk dapat mengakomodir berbagai konsep nasional dan membantu dalam menilai serta menganalisis berbagai dimensi kemiskinan. Argumentasinya adalah karena istilah kemiskinan sering terdengar negatif, maka istilah "kesejahteraan" membuat tentang pembahasan kemiskinan dapat dilakukan dari sisi positif. Oleh sebab itu, kemiskinan dalam artikel penelitian ini sering dimaknai sebagai 'kurangnya kesejahteraan" dan istilah "kesejahteraan" sebagai "kurangnya kemiskinan".

Tujuan pembangunan suatu negara adalah untuk mensejahterakan masyarakat. Meskipun berbagai program telah banyak dilaksanakan untuk pengentasan kemiskinan, namun masalah kemiskinan sampai saat ini masih terus menerus menjadi masalah yang berkepanjangan. Kemiskinan dan kesejahteraan merupakan dua konsep yang berbeda namun, keduanya saling berkaitan erat dan sebagai sebab akibat. Mereka dianggap belum sejahtera karena mereka masih miskin. Membahas dua konsep tersebut di atas sebenarnya membahas masalah lama namun, masalah tersebut hingga kini tetap menarik. Apa dan bagaimana profil kemiskinan, mengapa mereka miskin, apa sebab-sebabnya mereka bisa miskin dan sebagainya bukanlah masalah baru. Masalah kemiskinan di pedesaan semakin dikaji justru akan memperoleh sesuatu yang makin rumit dan menarik. Adanya dampak negatif modernisasi yang tak dapat mereka kuasai, membuat masalah kemiskinan menjadi semakin rumit dan berdimensi jamak, meski- 
pun berbagai program anti kemiskinan baik oleh pemerintah dan swadaya masyarakat telah dilakukan.

Berkaitan dengan penelitian sebelumnya, Penny (1990) Baharsjah (1992) Mubyarto (1994) Prasetyo $(2008,2009)$ dan seterusnya, diketahui bahwa kemiskinan yang parah dan meluas tampak lebih tajam di pedesaan, sehingga banyak penelitian tentang kemiskinan termasuk dalam artikel ini dipusatkan di wilayah daerah pedesaan. Hasil penelitian ini menunjukkan bahwa kemiskinan di daerah pedesaan sampel tidak semata-mata disebabkan hanya karena kurangnya modal agregat di pedesaan. Tetapi, juga disebabkan karena tidak meratanya penguasaan aset "modal" produksi, masih rendahnya kualitas sumber daya manusia, dan pola kepemilikan aset yang kecil dan kurang optimal pemanfaatannya.

Kepemilikan sebagian besar aset tanah di wilayah penelitian ini merupakan wilayah lereng pengunungan milik pemerintah, yang masih banyak ditanami pohon karet dan kayu lainnya. Sebagian besar mata pencaharian mereka adalah sebagai buruh tani, petani ladang dan pedagang, serta sedikit pegawai negeri. Karena sebagian besar warga masyarakat masih berpendidikan rendah, yakni tidak tamat Sekolah Dasar (SD) dan setingkat SD serta masih sedikit yang setingkat menengah dan atas, apalagi yang lulus perguruan tinggi, maka ini menandakan bahwa kualitas mutu kehidupan sumber daya manusia (SDM) masih rendah. Jika masalah kualitas mutu SDM dan human capital ini tidak segera ditangani, maka dikuatirkan masalah rendahnya kualitas SDM ini dapat menjadi penyebab utama gejala kemiskinan massal yang justru akan lebih mengerikan.

Berdasarkan kajian hasil penelitian ini, dapat dinyatakan bahwa segala masalah kemiskinan di daerah pedesaan ini diawali dengan adanya kualitas kehidupan SDM yang rendah, sehingga potensi pengembangan sumber daya lokal daerah ini rendah. Oleh sebab itu, sebagai salah satu solusinya yang terbaik, terlebih dahulu harus dapat membangun human capital (manusia pembangunan). Jika warga masyarakat kita dididik dan diberikan ketrampilan, pelatihan, baik secara intelektual, kultur dan mental-spiritual, maka akan bangkit kesadaran mereka untuk dapat melepaskan dirinya sendiri dan keluarga dari masalah kemiskinan, dan menjadi manusia penggerak pembangunan.

Hasil penelitian menegaskan bahwa ternyata tedapat masalah yang sangat krusial tentang kualitas kehidupan SDM di daerah penelitian ini, sehingga masalah SDM ini bukan hanya tanggungjawab pemerintah semata, tetapi juga tanggungjawab masyarakat luas termasuk kita. Jika dikaji lebih dalam, pemegang peranan terpenting untuk mempersiapkan SDM adalah keluarga inti, yang merupakan unit sosial terkecil dalam masyarakat. Dengan demikian, di pundak keluargalah semua harapan dan kemerdekaan hidup sejahtera diletakan. Karena itu, harus dibangun ketahanan keluarga dan perlindungan sosial keluarga, agar dapat melindungi diri dari pengaruh luar yang tidak sesuai dengan nilai dan norma keluarga, sehingga ke depan keluarga inti ini memiliki potensi daya saing yang lebih tinggi.

\section{Karakteristik dan Dinamika Kemiskinan di Daerah Penelitian}

Berdasarkan data kemiskinan dan hasil penelitian, wilayah daerah penelitian ini merupakan salah satu wilayah daerah yang banyak memiiki warga miskin. Hasil penelitian menunjukkan bahwa sebagian besar warga miskin di kecamatan ini berada di desa Wiru dan Desa Gogodalem. Di kedua desa ini, selain terdapat banyak warga miskin juga warga yang mengalami rawan pangan. Mengapa masalah kemiskinan dan rawan pangan dapat terjadi di wilayah ini? Bagaimana karakteristik serta dinamika kemiskinan dan rawan pangan yang terjadi wilayah ini? Seberapa besar dampak kemiskinan ini terjadi? Faktor dominan apa yang mempengaruhi kemiskinan mereka, serta bagaimana solusinya? Semua pertanyaan ini sangat menarik untuk dikaji dan dianalisis dalam artikel ini.

Secara teori maupun empiris, melacak sebab-sebab mengapa kemiskinan tersebut dapat terjadi, telah banyak dilakukan oleh pemerintah, lembaga, swadaya masyarakat maupun peneliti. Hasilnya dapat dinyatakan bahwa sebab-sebab kemiskinan terletak pada watak atau karakteristik dan perilaku orang miskin itu sendiri. Artinya, bagaimanapun ihwal pembe- 


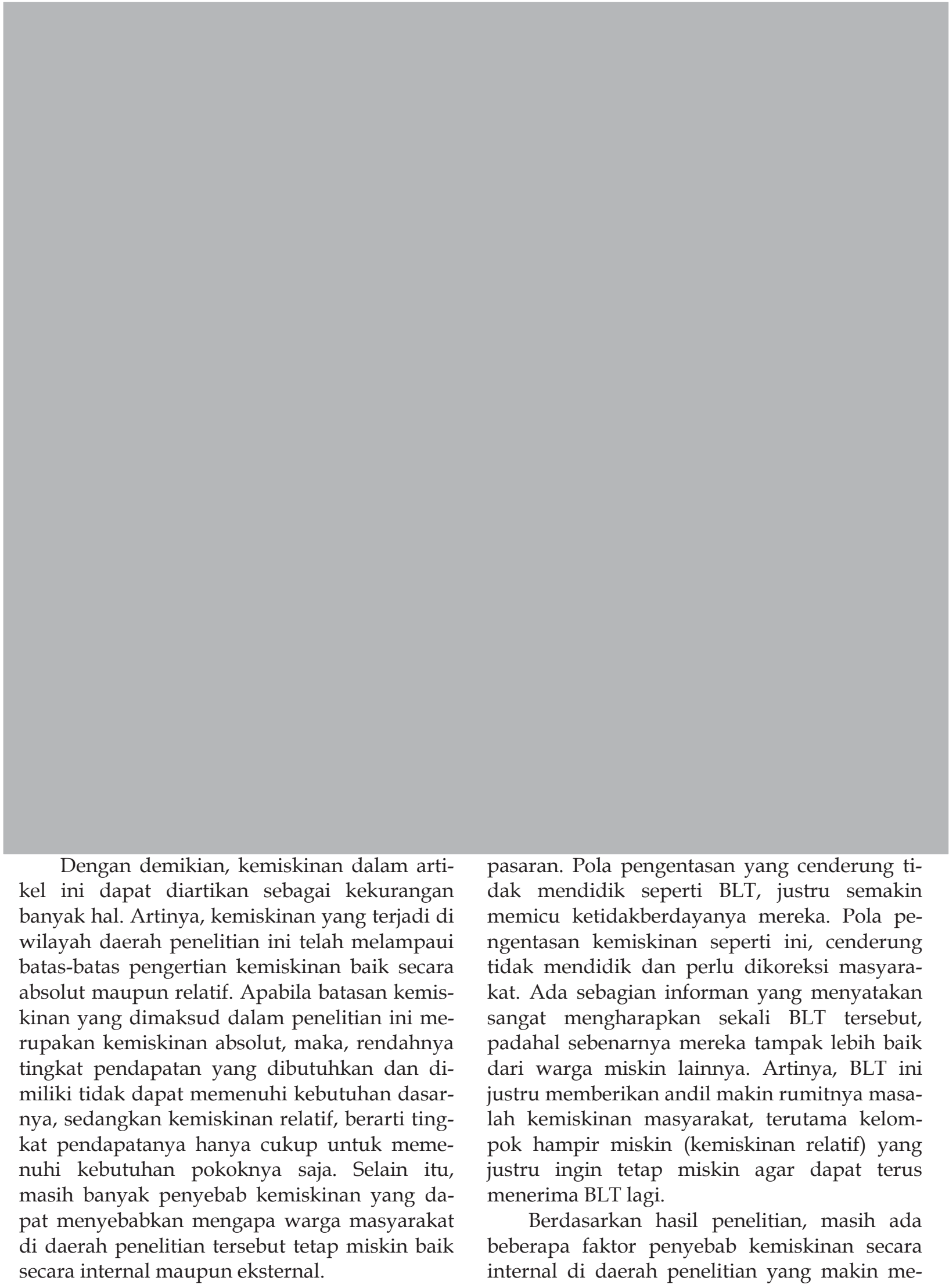

Model Kaji Tindak Program Pembangunan (P. Eko Prasetyo, dkk) 
nunjukkan kompleksitasnya masalah kemiskinan tersebut. Masalah kemiskinan ini jelas akan semakin rumit jika terus dikaji dari seluruh aspek kehidupan sosial, budaya, ekonomi dan politik mereka. Dari aspek ekonomi, karakteristik dan penyebab kemiskinan ini dapat dilihat dari matapencaharian warga miskin dan tingkat pendapatan yang diperoleh tetap rendah dan tidak mencukupi kebutuhan dasarnya. Ketika matapencaharian mereka semakin tidak banyak alternatif, maka tingkat pendapatan mereka makin rendah, dan pada gilirannya ketika tingkat pendapatan mereka tidak cukup memenuhi kebutuhan pokoknya, maka mereka menjadi semakin miskin lagi.

\section{Mata Pencaharian Pokok Warga Miskin}

Hasil penelitian menunjukkan bahwa pekerjaan utama rumah tangga keluarga miskin dan rawan pangan di daerah penelitian sebagian besar sebagai buruh tani dan petani ladang. Ketika musim kemarau tiba, maka mata pencaharian petani miskin yang semula sebagai petani padi beralih menjadi petani jagung atau ubi. Ketika itu pula, jumlah rumah tangga rawan pangan yang bekerja sebagai buruh tani makin banyak. Secara lebih rinci mengenai pekerjaan KK rawan pangan pada tahun 20082009 di wilayah daerah penelitian dapat didiskripsikan seperti pada Tabel 1.

Pada Tabel 1 menunjukkan bahwa dari 126 responden rumah tangga miskin dan rawan pangan terdapat 92 (73,02 persen) adalah buruh tani dan 34 (26,98 persen) sebagai petani. Selain sebagai buruh tani, karakteristik warga pada Desa V (Gogodalem) adalah salah satu contoh desa yang cukup banyak rumah tangga miskin sebagai petani tadah hujan yakni; petani padi, ubi kayu dan jagung. Ketika musim kemarua tiba, kehidupan mereka beralih menjadi petani ubi atau jagung. Kondisi tersebut justru menunjukkan bahwa kehidupan warga petani miskin seperti ini masih rentan terhadap rawan pangan. Namun, pada Desa V ini jumlah penduduk rawan pangannya lebih sedikit dibanding desa I (Wiru). Barangkali masalah ini yang membuat keputusan Pemerintah Daerah setempat memutuskan bahwa Desa Wiru dijadikan sebagai sentra desa percontohan program mandiri pangan.

Jika dikaji lebih lanjut, sebagian besar kehidupan warga miskin yang sebagai petani ini juga tidak memiliki tanah ladang yang cukup. Untuk warga petani yang mengaku tidak miskin saja hanya memiliki paling luas rata-rata kurang dari 0,5 hektar. Selain itu, lahan tersebut sebagian besar kurang subur, karena kondisi air di wilayah ini sangat kurang. Hal ini logis, karena daerah ini adalah merupakan daerah lereng pegunungan yang sumber airnya hanya dari curah hujan saja, sehingga sumber air untuk kehidupan ketika di musim kemarau menjadi terasa sangat sulit. Dampak berikutnya, kekurangan air sebagai sumber kehidupan ini jelas semakin terasa, dan air sebagai sumber kehidupan pertanian mereka juga sangat lang$\mathrm{ka}$, sehingga hasil pertanian mereka menjadi kurang subur. Selanjutnya, ketika hasil pertanian mereka sudah tidak dapat diandalkan lagi, maka mereka akan mengalami kemiskinan dan rawan pangan sebagaimana kehidupan ini berutar. Kehidupan ini semakin dirasakan parah jika mereka mengaku sebagai petani, tetapi

Tabel 1. Mata Pencaharian Responden Sampel Rumah Tangga Miskin dan Rawan Pangan di Wilayah Daerah Penelitian Kecamatan Bringin Kabupaten Semarang

\begin{tabular}{lcccccc}
\hline \multicolumn{1}{c}{ RW } & Pekerjaan Responden & & Total & Persen \\
& Petani & Persen & Buruh & Persen & & \\
\hline Desa I & 4 & 3,17 & 23 & 18,25 & 27 & 21,42 \\
Desa II & 5 & 3,97 & 16 & 12,70 & 21 & 16,67 \\
Desa III & 2 & 1,59 & 11 & 8,73 & 13 & 10,32 \\
Desa IV & 4 & 3,17 & 14 & 11,11 & 18 & 14,28 \\
Desa V & 16 & 12,70 & 19 & 15,08 & 35 & 27,78 \\
Desa VI & 3 & 2,38 & 9 & 7,15 & 12 & 9,53 \\
$\quad$ Total & 34 & 26,98 & 92 & 73,02 & 126 & 100 \\
\hline
\end{tabular}

Sumber: Data Primer, 2009 
mereka sendiri tidak memiliki ladang pertanian dan tidak memiliki alternatif pekerjaan lain selain bertani.

\section{Mata Pencaharian Tambahan Warga Miskin}

Pada umumnya, responden telah menjelaskan bahwa pekerjaan pokok mereka adalah sebagai petani dan buruh tani. Selain itu, sebagian besar responden tidak memiliki pekerjaan sampingan lain, yakni sebesar 88 rumah tangga atau $(69,84$ persen). Ada sebayak 38 responden atau 30,16 persen dari warga miskin dan rawan pangan yang memiliki pekerjaan sampingan selain pekerjaannya sebagai petani dan buruh tani adalah; sebagai pekerja serabutan, buruh pabrik/ bagunan, pembantu rumah tangga, dan pedagang kecil-kecilan atau warung kaki lima. Hasil penelitian ini selengkapnya dapat dilihat pada Tabel 2. Jika kita lihat, pekerjaan sebagai buruh bangunan atau buruh pabrik masih sedikit sebenarnya cukup aneh, karena pada dasarnya wilayah daerah ini cukup dekat dengan Wilayah kota Kabupaten Semarang yang notabene cukup banyak industri.

Masih banyaknya rumah tangga miskin ini yang tidak memiliki pekerjaan sampingan selain sebagai petani dan buruh tani adalah semakin menyulitkan atau memiskinkan mereka sendiri ketika musim kemarau tiba. Fenomena ini sering terjadi, ketika musim kemarau hasil mereka jelas berkurang, yang berarti pula pendapatan mereka semakin kecil, padahal mereka sendiri tidak memiliki sumber-sumber pendapatan lainnya. Kondisi tersebut berarti menunjukkan bahwa produktivitas mereka rendah, maka dampak berikutnya daya beli dan daya saing mereka juga makin rendah. Rendahnya produktivitas ini berarti mendiskripsikan ketidakberdayaan mereka. Namun demikian, apa yang menjadi penyebab utama mereka tidak berdaya ini? Apakah mereka malas atau karena ketidaktahuannya? Bagaimana cara memberdayakan mereka ini, adalah sesuatu hal yang sangat urgen untuk terus dikaji lebih lanjut pada penelitian tahap berikutnya.

Hasil penelitian yang didukung data pada Tabel 2, makin menegaskan deskripsi bahwa karakteristik mengapa mereka miskin, memang karena mereka sendiri miskin. Pola kemiskinan ini tidak hanya disebabkan karena memang mereka tidak saja memiliki pekerjaan sampingan lainnya. Hal ini dapat dimungkinkan karena mereka tidak memiliki alternatif pekerjaan yang lebih baik lainnya. Mengapa mereka tidak memiliki alternatif pekerjaan baik lainnya, karena mereka memang tidak mengetahui pekerjaan alternatif lain apa yang dapat mereka kerjakan. Dengan demikian dapat dimaknai bahwa masalah pokok mereka sebenarnya adalah ketidaktahuan mencari pekerjaan lain karena memang mereka tidak memiliki pengetahuan dan skill lain selain sebagai petani dan buruh tani. Hasil penelitian ini justru semakin menarik secara akademik untuk terus ditindak lanjuti melalui kajian penelitian berikutnya.

\section{Tingkat Pendapatan Warga Miskin}

Rata-rata tingkat pendapatan warga miskin dan rawan pangan ini adalah Rp300.000 per bulan, dengan tingkat pendapatan terendah kurang dari Rp200.000,00 dan tingkat pendapatan tertinggi sebesar Rp650.000. Sedangkan, yang le-

Tabel 2. Mata Pencaharian Sampingan Responden Warga Miskin dan Rawan Pangan

\begin{tabular}{|c|c|c|c|c|c|c|c|c|c|c|c|c|}
\hline \multirow[t]{3}{*}{ Desa } & \multicolumn{10}{|c|}{ Jenis Pekerjaan } & \multicolumn{2}{|c|}{ Total } \\
\hline & \multicolumn{2}{|c|}{ Tdk punya } & \multicolumn{2}{|c|}{ Serabutan } & \multicolumn{2}{|c|}{ Buruh } & \multicolumn{2}{|c|}{ Pembantu } & \multicolumn{2}{|c|}{ Pedagang } & \multirow[b]{2}{*}{$\mathrm{Jml}$} & \multirow[b]{2}{*}{$\%$} \\
\hline & $\mathrm{Jml}$ & $\%$ & $\mathrm{Jml}$ & $\%$ & $\mathrm{Jml}$ & $\%$ & Jml & $\%$ & Jml & $\%$ & & \\
\hline I & 20 & 15,87 & 3 & 2,38 & 2 & 1,59 & 1 & 0,79 & 1 & 0,79 & 27 & 21,42 \\
\hline II & 14 & 11,11 & 5 & 3,97 & 0 & - & 0 & - & 2 & 1,59 & 21 & 16,67 \\
\hline III & 7 & 5,55 & 0 & - & 3 & 2,38 & 2 & 1,59 & 1 & 0,79 & 13 & 10,32 \\
\hline IV & 13 & 10,32 & 2 & 1,59 & 0 & - & 1 & 0,79 & 2 & 1,59 & 18 & 14,28 \\
\hline V & 24 & 19,05 & 6 & 4,76 & 4 & 3,17 & 0 & - & 1 & 0,79 & 35 & 27,78 \\
\hline VI & 10 & 7,94 & 1 & 0,79 & 0 & - & 1 & 0,79 & 0 & - & 12 & 9,53 \\
\hline Total & 88 & 69,84 & 17 & 13,49 & 9 & 7,14 & 5 & 3,97 & 7 & 5,55 & 126 & 100 \\
\hline
\end{tabular}

Sumber: Data primer, 2009 
Tabel 3. Tingkat Pendapatan Responden Warga Miskin dan Rawan Pangan (Rp/bulan)

\begin{tabular}{|c|c|c|c|c|c|c|c|c|c|c|}
\hline \multirow{3}{*}{ Desa } & \multicolumn{8}{|c|}{ Tingkat Pendapatan Responden Sampel (Rp000) } & \multirow{2}{*}{\multicolumn{2}{|c|}{ Total }} \\
\hline & \multicolumn{2}{|c|}{ Rp50-Rp200 } & \multicolumn{2}{|c|}{ Rp200-Rp350 } & \multicolumn{2}{|c|}{ Rp350-Rp500 } & \multicolumn{2}{|c|}{ Rp500-Rp650 } & & \\
\hline & Jml & $\%$ & Jml & $\%$ & Jml & $\%$ & Jml & $\%$ & Jml & $\%$ \\
\hline I & 3 & 3,17 & 14 & 10,32 & 9 & 7,14 & 1 & 0,79 & 27 & 21,42 \\
\hline II & 2 & 1,59 & 11 & 8,73 & 7 & 5,55 & 1 & 0,79 & 21 & 16,67 \\
\hline III & 0 & - & 6 & 4,76 & 6 & 4,76 & 1 & 0,79 & 13 & 10,32 \\
\hline IV & 1 & 0,79 & 7 & 5,55 & 10 & 7,94 & 0 & - & 18 & 14,28 \\
\hline $\mathrm{V}$ & 7 & 5,55 & 18 & 14,29 & 8 & 6,35 & 2 & 1,59 & 35 & 27,78 \\
\hline VI & 3 & 2,38 & 6 & 4,76 & 3 & 2,38 & 0 & - & 12 & 9,53 \\
\hline Total & 16 & 12,70 & 62 & 49,21 & 43 & 34,13 & 5 & 3,97 & 126 & 100 \\
\hline
\end{tabular}

Sumber: Data primer, 2009

bih menyedihkan adalah warga miskin yang memiliki tingkat pendapatan antara Rp500.000Rp650.000 justru lebih sedikit yakni sebesar 3,97 persen dibanding yang tingkat pendapatannya kurang dari Rp200.000 ada sebanyak 12,70 persen. Fenomena ini menegaskan bahwa masalah kemiskinan yang terjadi di daearah penelitian tersebut dapat dinyatakan karena memang rendahnya tingkat pendapatan mereka.

Ketika pendapatan mereka rendah, maka daya beli mereka juga rendah, akibatnya akses mereka terhadap kepemilikan aset yang lain juga rendah. Rendahnya kepemilikan aset tersebut berdampak pada daya saing mereka juga rendah, karena mereka semakin tidak banyak memiliki alternatif lain yang lebih baik. Dengan kata lain, ketika pendapatan yang mereka miliki rendah, maka kepemilikan mereka terhadap pemenuhan kebutuhan pokok mereka juga rendah. Artinya kemiskinan ini secara mutlak terbukti telah terjadi, sebab pendapatannya tidak dapat memenuhi kebutuhan pokok esensi mereka. Sebagian besar dari pendapatan ini, mereka gunakan hanya untuk memenuhi kebutuhan pokok konsumsi makan sehari-hari saja dan sangat sulit untuk memenuhi kebutuhan pokok lainnya seperti, kesehatan dan pendidikan yang lebih baik. Jika dikaji lebih lanjut, ternyata konsumsi makan mereka sebagian besar hanya berkualitas rendah, yang berarti gizi mereka juga rendah. Konsumsi makan mereka memang tampak tidak masalah dari segi kelancaran. Namun, dari segi asupan gizinya masih tergolong rendah, karena konsumsi mereka jarang menggunakan lauk-pauk yang bergizi termasuk kurang memperhatikan konsumsi garam berzodium.
Dinamika dan karakteristik masalah kemiskinan menjadi semakin parah dan paling parah justru ketika seseorang responden tidak hanya merasa miskin, tetapi juga kekurangan kemampuan untuk memiliki sarana dan prasarana agar ke luar dari kemiskinannya. Dengan demikian, kemiskinan tidak hanya "tidak mempunyai ikan" atau BLT, tetapi mereka justru "tidak tahu" menangkap ikan, atau "tidak memiliki pancing atau jaring" bahkan "tidak memiliki hak untuk menangkap ikan". Artinya, ketika mereka merasa tidak memiliki BLT, maka mereka merasa miskin dan tidak tahu lagi bagaimana cara memperolehnya, karena mereka juga terbatas informasinya, tidak memiliki kedekatan dengan aparat atau petugas penyalur BLT, dan mereka merasa tidak dapat hak untuk mengajukannya. Dengan kata lain, karakteristik masalah kemiskinan menjadi semakin dinamis dan sangat multidimensi serta makin berantai (multiplier effect) dalam kehidupan masyarakat. Artinya, fenomena ini ikut membenarkan pernyataan Ragnar Nurkse dalam Kuncoro (2003) bahwa mereka miskin karena ia memang miskin (a poor country is because it is poor).

Pada Gambar 1 tampak bahwa karakteristik dan dinamika penyebab masalah kemiskinan di wilayah daerah penelitian Kecamatan Bringin Kabupaten Semarang dapat dideskripsikan bagaikan bermuara pada teori lingkaran setan kemiskinan (vicious circle poverty). Bagaimana solusinya agar mereka dapat keluar dari masalah kemiskinan dan keterbelakangan tersebut adalah menarik untuk terus dikaji dalam artikel penelitian ini baik secara empiris maupun teoritis. 


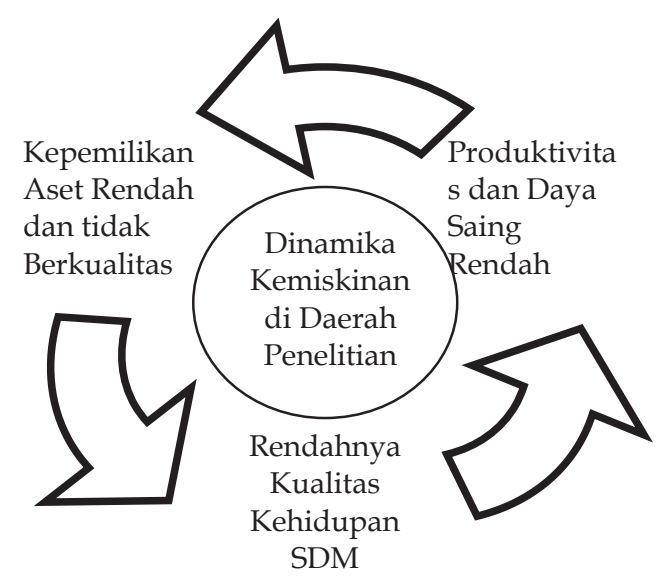

Gambar 1. Karakteristik dan Dinamika Kemiskinan di Wilayah Daerah Penelitian

Secara empiris, pada umumnya di wilayah daerah-daerah pedesaan yang miskin sering terjebak dalam kemiskinan dan keterbelakangan ini. Karena wilayah pedesaan ini pada prinsipnya hanya meningkatkan akumulasi modal fisik (K), jumlah fisik tenaga kerja orang (L) dan kurangnya memupuk kapital sumber daya manusia $(\mathrm{H})$, yang didukung kurang berfungsinya peran intervensi kelembagaan pemerintah (ekonomi kelembagaan setempat). Selain itu, kurang memikirkan kuantitas dan kualitas kehidupan melalui pendidikan, latihan dan keterampilan (A) secara konsisten dan berkesinambungan. Dampak berikutnya, proses pembangunan yang dihasilkan mereka kaum miskin ini menjadi tidak berkualitas dan tetap miskin. Oleh karena itu, peluang meningkatkan kualitas hidup masyarakat melalui peningkatan faktor (A) menjadi semakin penting dan sangat mendesak untuk terus diperluas agar dapat menentukan nasibnya sendiri secara merdeka, mandiri dan berkelanjutan. Dengan kata lain, perluasan dan peningkatan faktor atau variabel A tersebut dapat memutus tataran keterbelakangan warga masyarakat miskin menuju ke tataran yang lebih maju (vicious circle menjadi vituous circle).

Penjelasan di atas dapat diilustrasikan sebagai model fungsi peningkatan kesejahteraan sebagai berikut.

$$
Y_{(t)}=K_{t}^{\alpha}, H_{t}^{\beta}\left[A_{t}, L_{t}\right]^{1-\alpha-\beta}
$$

di mana $\alpha>0, \beta>0$ dan $\alpha+\beta<1$.
Artinya adalah bahwa peningkatan kesejahteraan warga masyarakat pada kurun waktu tertentu $\left(\mathrm{Y}_{\mathrm{t}}\right)$ atau dapat dibaca pengurangan kemiskinan pada suatu waktu tertentu, akan tejadi atau berhasil jika ada fungsi peningkatan penguasaan modal atau kapital $\left(\mathrm{K}_{\mathrm{t}}\right)$, peningkatan human capital $\left(\mathrm{H}_{\mathrm{t}}\right)$ dan peningkatan kreatifitas dan keterampilan atau skill $\left(\mathrm{A}_{\mathrm{t}}\right)$ dari sejumlah keluarga inti atau warga masyarakat miskin setempat $\left(L_{t}\right)$. Secara parsial, masalah ini juga dapat dijelaskan dengan asumsi dinamika $\mathrm{K}$ dan L sebagai berikut.

$$
\begin{aligned}
& \dot{K}(t)=S K Y(t) \\
& \dot{L}(t)=n L(t),
\end{aligned}
$$

$S_{K}$ adalah akumulasi kapital fisik, dan diasumsikan tidak ada depresiasi. Selanjutnya, pertumbuhan teknologi adalah konstan dan eksogeneous.

$\dot{A}(t)=g A(t)$,

Dalam hal ini, akumulasi modal manusia atau human capital dapat dimodelkan sama dengan akumulasi modal fisik sebagai berikut.

$$
\dot{H}(t)={ }_{\mathrm{SH}} \mathrm{Y}(\mathrm{t}),
$$

\section{Peran Keluargan dalam Pengentasan Kemiskinan}

Keluarga inti sebagai unit kelompok terkecil di masyarakat, mempunyai peran yang signifikan dalam pengentasan kemiskinan. Oleh karena itu, model kaji tindak perluasan program pembangunan ini difokuskan pada pengembangan dan pemberdayaan keluarga. Upaya ini ditujukan agar ke depan paling tidak tujuan pembangunan mampu mensejahterakan keluarga miskin secara mandiri dan berkelanjutan. Upaya ini dapat dilakukan melalui kaji tindak peningkatan kualitas keluarga yang bercirikan kemandirian dan ketahanan keluarga yang lebih tinggi dalam rangka mewujudkan berbagai perluasan program pembangunan yang lebih bahagia dan sejahtera secara mandiri dan berkelanjutan.

Berdasarkan tujuan tersebut, maka berbagai program kaji tindak pembangunan lebih diarahkan pada peningkatan sikap mental dan 


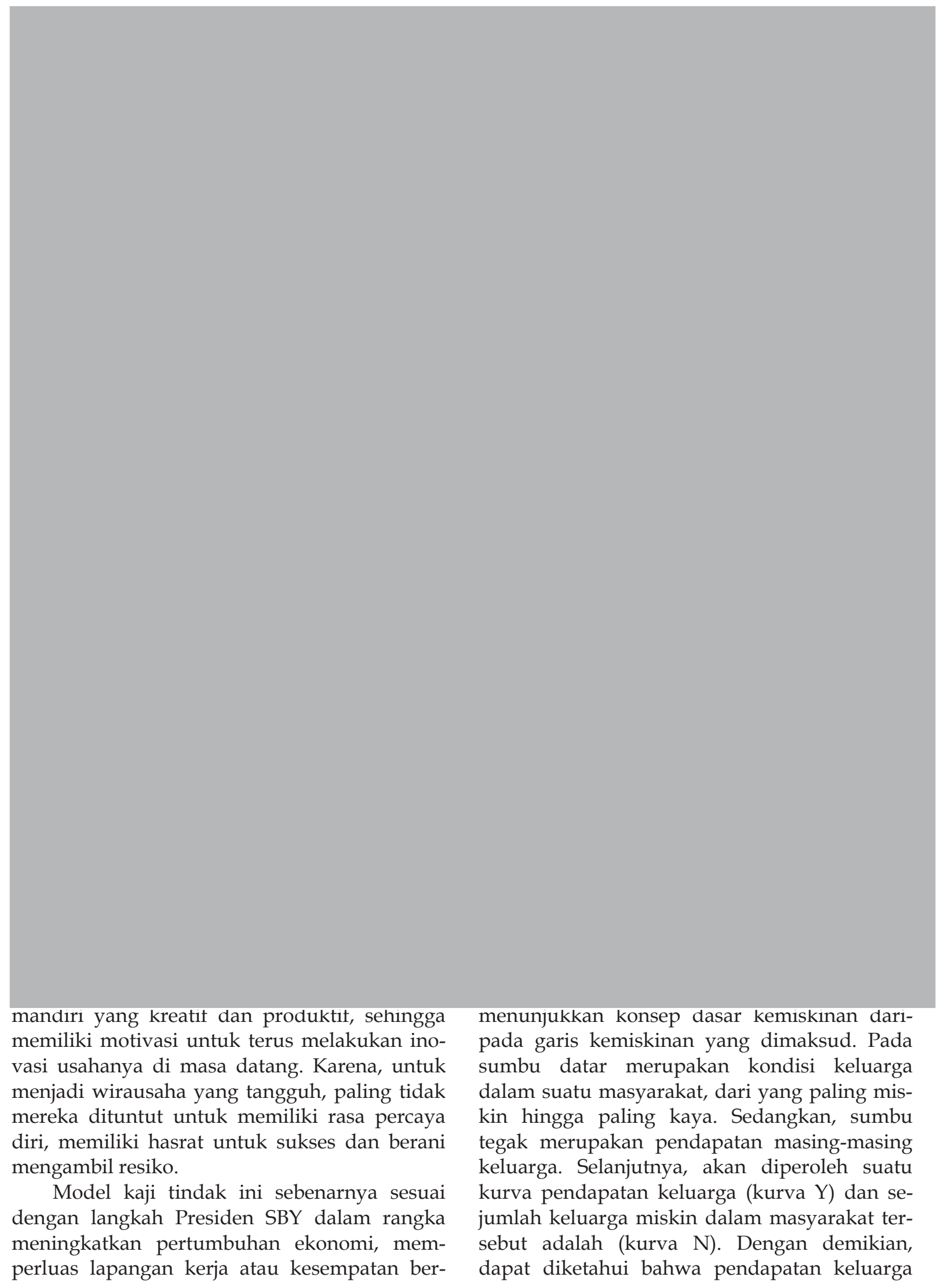


paling miskin adalah sebesar $\mathrm{Y}_{0}$, sedangkan pendapatan keluarga orang miskin paling besar adalah $Y_{1}$. Selisih antara $Y_{0}$ dan $Y_{1}$ tersebut inilah yang mencerminkan permasalahan distribusi pendapatan keluarga miskin. Namun, jika $\mathrm{Y}_{\mathrm{Z}}$ merupakan garis kemiskinan, maka keluarga yang pendapatannya di bawah $\mathrm{Y}_{Z}$ dianggap keluarga miskin sekali dan di atas $Y_{Z}$ adalah kemiskinan relatif.

Jika Tabel 3 dikaitkan dengan Gambar 2, tampak bahwa titik a adalah titik keseimbangan antara batas rata-rata tingkat pendapatan warga miskin dan rawan pangan dengan tingkat kesejahteraan yang dapat mereka raih. Jika garis vertikal pada Gambar 2 adalah menunjukkan tingkat pendapatan warga miskin dan garis horisontal menunjukkan tingkat kesejahteraan warga miskin yang dapat diraih. Karena itu, ketika tingkat pendapatan mereka lebih tinggi yakni mencapai tingkat $\mathrm{Y}_{1}$, atau sebesar, Rp650.000 yakni terjadi keseimbangan di titik b, maka kondisi kesejahteraan warga miskin akan tampak lebih baik, dibanding ketika tingkat pendapatannya masih sebesar $Y_{Z}$. Dengan demikian, titik $b$ merupakan tingkat kondisi kehidupan warga miskin yang lebih baik. Oleh karena itu, beban orang miskin ini perlu dikurangi melalui peningkatan tingkat pendapatan mereka. Masalah berikutnya adalah bagaimana cara meningkatkan tingkat pendapatan orang miskin yang tetap produktif tersebut dan tidak melalui cara seperti pemberian BLT atau Raskin? Permasalahan ini sangat urgen untuk terus dikajitindaki dalam penelitian berikutnya.

Melalui metode penelitian kaji tindak ini, maka salah satu cara yang dapat digunakan sebagai solusi tersebut, adalah digunakan empat pilar model pengentasan kemiskinan, yang salah satu pilarnya adalah dengan cara memberikan peluang kesempatan kerja dan berusaha. Model ini sangat argumentatif, karena hasil penelitian menunjukkan bahwa pada dasarnya masih banyak sumber daya di wilayah daerah penelitian ini yang belum digunakan secara optimal. Sebagai contoh masih banyaknya tanaman pohon bambu yang belum digunakan secara optimal selain hanya sebagai bahan bangunan rumah. Selain itu, hasil panen jagung dan ubi kayu juga hanya dikonsumsi begitu saja tanpa diolah lebih lanjut, sehingga memperoleh nilai tambah lebih dan memberikan kesempatan kerja. Ada beberapa desa di Kecamatan Bringin yang memiliki sumber daya produktif tetapi belum dimanfaatkan secara optimal. Misalkan desa: Popongan, Truko, Banding, Sendang, Gogodalem, Rembes, Kalijambe, Pakis dan Bringin sendiri merupakan desa potensial sumber daya lokal bambu dan kayu. Sedangkan desa; Gogodalem, Wiru, Banding, Kalikurmo, Pakis, dan Sendang adalah desa potensial sumber daya penghasil jagung, ubi kayu, kacang tanah dan kedelai. Selain itu, hampir sebagian besar dari 16 desa di wilayah kecamatan Bringin ini selain potensi padi, adalah sangat potensial sebagai penghasil kayu dan jagung, karena memang letak wilayah kecamatan Bringin ini berada di lereng pegunungan yang dikelilingi hutan kayu. Hanya saja sebagian besar hutan kayu tersebut adalah milik pemerintah dan bukan milik warga sendiri.

Dengan demikian, secara empiris dan teo-

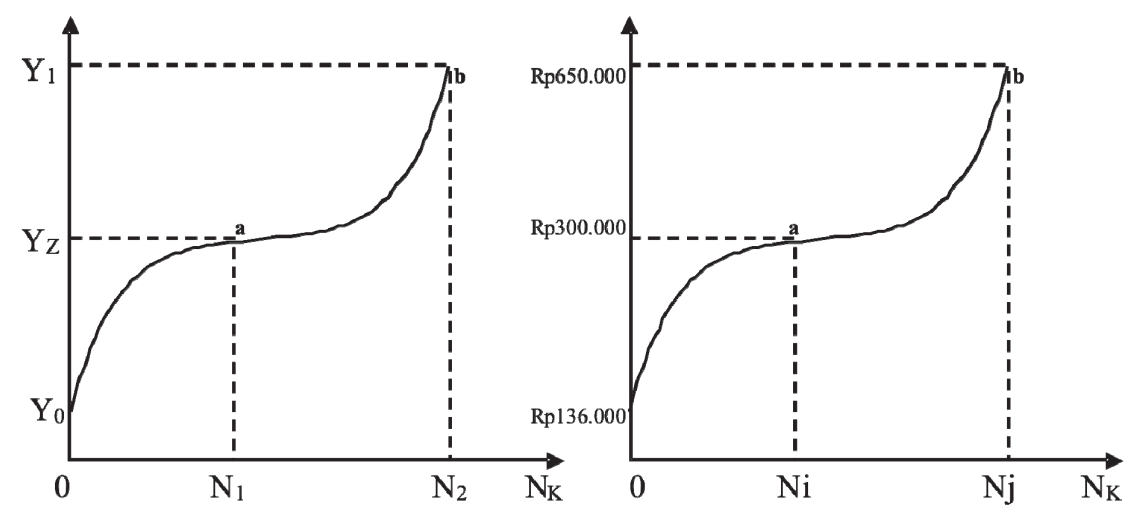

Gambar 2. Fungsi Pendapatan Keluarga Miskin dan Penentuan Garis Kemiskinan di Daerah Penelitian 
ritis, masyarakat miskin di wilayah daerah penelitian ini secara umum menghadapi permasalahan terbatasnya kesempatan kerja dan berusaha, terbatasnya peluang pengembangan usaha, lemahnya perlindungan terhadap aset usaha, terbatasnya modal usaha, dan kurangnya keterampilan dasar maupun pengetahuan yang dimiliki mereka, akibatnya mereka hanya sedikit sekali mimiliki alternatif pilihan pekerjaan yang layak. Terbatasnya lapangan pekeriaan dan usaha vane teriadi di wilavah daerah syarakat bawah. Pada Gambar 3, permasalahan penguatan peran serta masyarakat merupakan kunci utama dalam proses pembangunan di daerah miskin dan rawan pangan ini. Termasuk dalam konteks ini adalah bagaimana membangkitkan seluruh potensi masyarakat desa dan kecamatan terkait (Bringin), untuk mengembangkan dan memanfatkan ilmu pengetahuan dasar dan sosial budaya (idigenous knowledge dan culture social) yang ada. Tujuan proses ini adalah untuk merevitalisasi modal sosial lokal

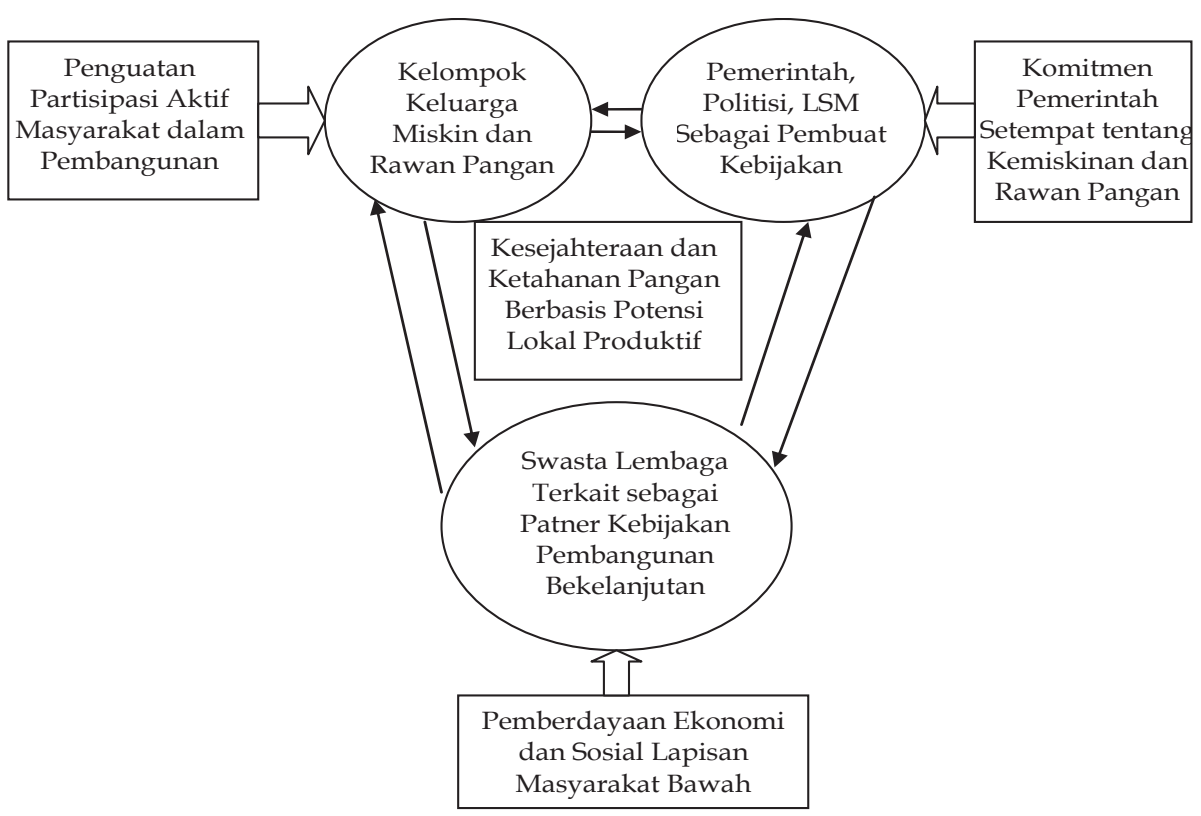

Gambar 3. Model Keterkaitan Partisipasi Aktif Masyarakat dalam Mewujudkan Kesejahteraan dan Mandiri Pangan Berbasis Kekuatan Potensi Lokal di Daerah Penelitian 
peran serta aktif yang lebih besar kepada mereka agar menjadi subyek dalam pembangunan atau sebagai manusia pembangunan dan bukan sebagai beban pembangunan.

Oleh karena itu, direkomendasikan masih perlu dikaji dan disusun suatu model pemberdayaan lapisan bawah ini untuk lebih mempercepat terwujudnya kemandirian dan keberlanjutan ketahanan pangan rumah tangga miskin dan rawan pangan di seluruh wilayah daerah penelitian. Tujuan lainnya adalah untuk mereview kembali model dasar pengentasan kemiskinan ini agar lebih cepat diketahui tingkat keberhasilannya. Karena, hasil penelitian menunjukkan bahwa; implementasi pertama program desa mandiri pangan yang dipusatkan di Desa Wiru Kecamatan Bringin ini baru berjalan dua tahun, dan sampai saat ini baru pada tahap penumbuhan kelompok aktivitas. Pada tahap tersebut, implementasi di seluruh wilayah penelitian dirasa masih sangat kurang, sehingga perlu dilakukan percepatan dan perluasan ke seluruh desa di wilayah penelitian.

\section{Model Kaji Tindak Perluasan Program Pembangunan}

Kemiskinan merupakan persoalan serius yang memerlukan penanganan secara intensif dan selalu diusahakan untuk diminimalisir, karena kemiskinan adalah suatu fenomena yang sangat kompleks dan bersifat multidimensional dan multieffect, tetapi pada kenyataannya kemiskinan masih menjadi masalah yang selalu melekat dalam setiap sendi kehidupan masyarakat di Indonesia, tidak terkecuali di wilayah penelitian ini. Konsentrasi warga masyarakat miskin di daerah penelitian yang berada di wilayah daerah pegunungan, dapat diketahui bahwa tidak tersedia resep tunggal untuk solusi yang mujarab pada kasus ini. Namun, peneliti mencoba untuk menjelaskan cara termudah bagaimana cara mengentaskan kemiskinan di daerah ini.

Masyarakat miskin tidak merupakan satu kelompok miskin yang sama, sehingga harus lebih memahami karakter khusus masing-masing kelompok jika ingin menemukan cara yang paling efektif dalam menangani kemiskinan. Dengan demikian, tim peneliti dalam penelitian ini perlu mengembangkan instrumen khusus sebagai respon atau tanggapan terhadap situasi khusus tertentu dan pada saat yang sama menyesuaikan instrumen khusus tersebut dengan situasi yang baru. Setelah konsentrasi masyarakat miskin di daerah ini dapat dipetakan, barulah kemudian dapat diketahui di mana persentase penduduk miskin terbesar, misalnya di Desa Wiru atau Desa Gogodalem, maka wilayah konsentrasi tersebut ditetapkan sebagai desa atau kelurahan sampel dan selanjutnya permasalahan kasus ini dapat diperinci lebih lanjut setelah penelitian ini selesai. Karena itu, penelitian ini berangkat dari asumsi bahwa pemantauan dan penelitian pada periode kedua akan dihasilkan hasil yang lebih baik. Selanjutnya, prinsip-prinsip kunci dasar penelitian kaji tindak berdasarkan partisipatif masyarakat ini telah diimplementasikan sebagaimana pada Gambar 4 dan Gambar 5.

Karena penelitian ini diharapkan dapat dihasilkan sesuai program nasional, maka model dasar kaji tindak program pengentasan kemiskinan ini adalah UU No. 5/2000 tentang penanggulangan kemiskinan nasional yang terdapat empat pilar tersebut, dan lima pilar penanggulangan kemiskinan di Jawa Tengah. Namun demikian, satu pilar dari lima pilar tersebut merupakan pengembangan dari empat pilar, sehingga pada penelitian tahap pertama ini baru lebih difokuskan pada empat pilar pokok tersebut dan khususnya pilar peningkatan kesempatan kerja dan berusaha serta pilar perlindungan sosial. Jika model pengentasan kemiskinan ini dapat diibaratkan bagaikan membangun sebuah rumah, maka pilar-pilar tersebut dapat digambarkan seperti pada Gambar 4.

Jika masalah kemiskinan warga miskin dan rawan di wilayah daerah penelitian ini dapat diasumsikan sebagaimana kondisi masih kecilnya tingkat pendapatan mereka sehingga mereka warga miskin dan rawan ini merasa bagaikan memikul beban beratnya. Sebab, dengan tingkat pendapatan yang rendah, daya beli dan daya saing mereka juga rendah, akibatnya mereka tidak dapat mengakses sumber daya lain di pasar untuk memenuhi kehidupannya. Oleh karena itu, masalah rendahnya tingkat pendapatan ini perlu ditingkatkan dan besarnya beban berat ini perlu dikurangi. 


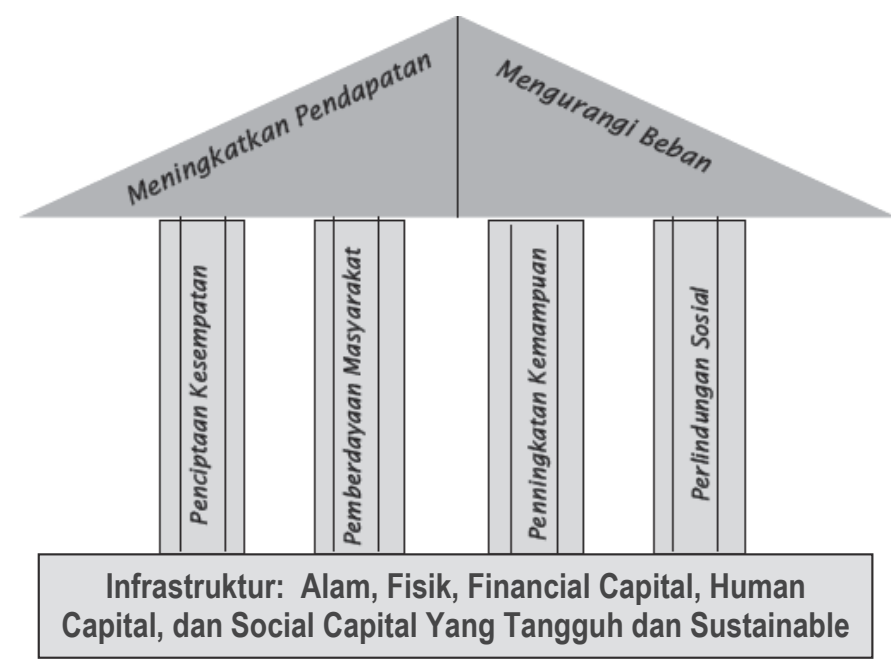

Gambar 4. Model Pengentasan Kemiskinan dan Rawan Pangan di Daerah Penelitian

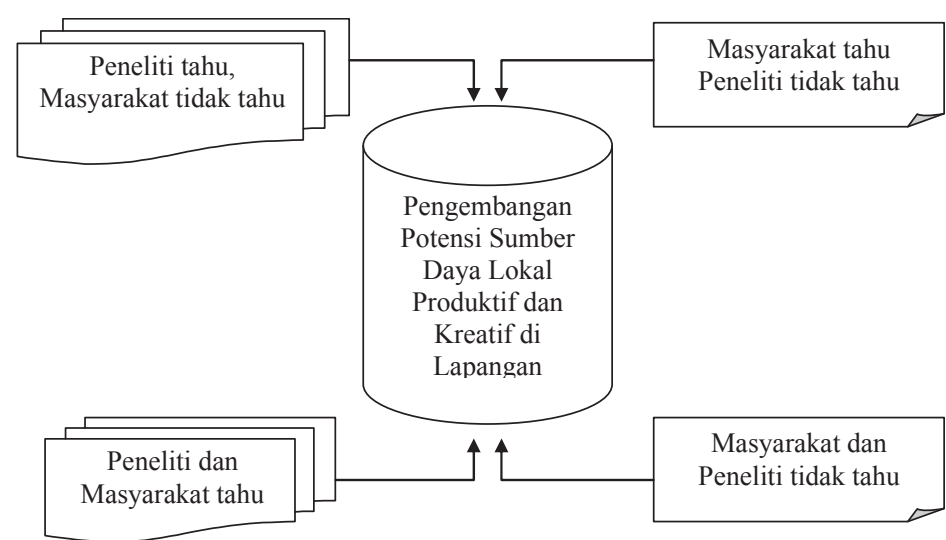

Sumber: Modifikasi dari Niehof el all., (2003)

Gambar 5. Model Kaji Tindak Partisipatif untuk Pengentasan Kemiskinan 


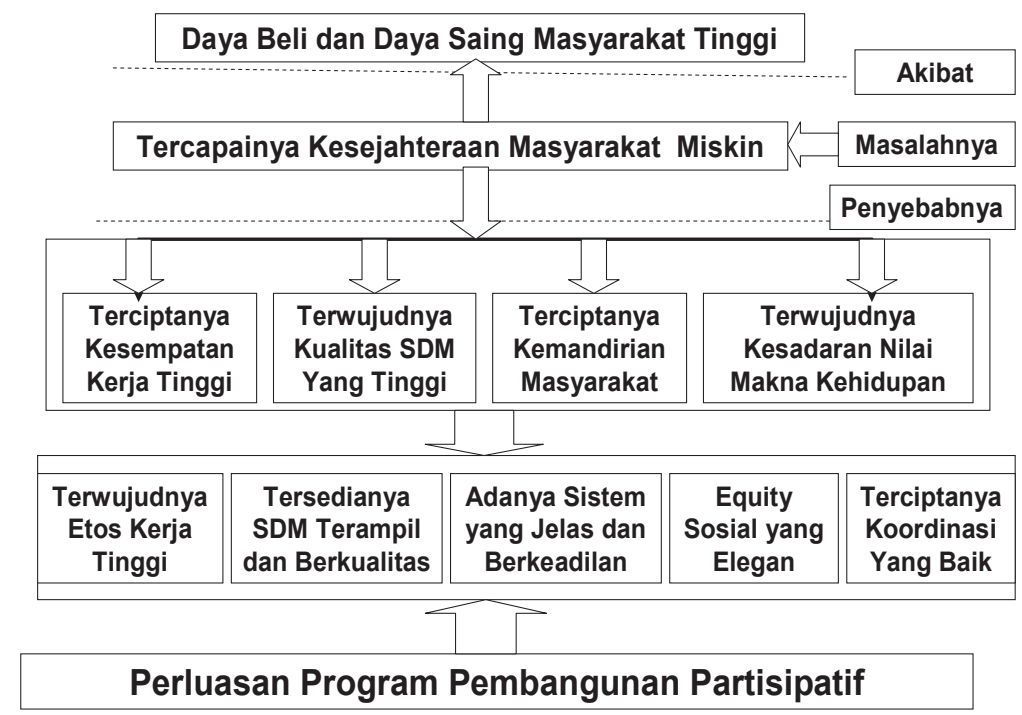

Gambar 6. Pohon Sasaran Pernyataan Positif Pengentasan Kemiskinan

dalam penelitian yang berbasis masyarakat ini, maka partisipasi keterlibatan masyarakat setempat adalah sangat penting, yakni seperti halnya pada Gambar 5.

Selanjutnya, jika sudah diketemukan berbagai sumber daya potensial yang dapat dikembangkan, dan disepakati untuk dikembangkan melalui FGD, maka selanjutnya tim peneliti memberikan solusinya bagaimana cara mengembangkan dan memaksimalkan sumber daya potensial kearifan lokal tersebut secara esensial menjadi semakin nyata. Karena kemiskinan merupakan masalah yang multidimensi, maka semua potensi yang ada baik secara ekonomi, sosial, politik dan budaya masyarakat setempat secara riil perlu dimaksimalkan, sebagai upaya pengentasan kemiskinan.

Hasil penelitian menegaskan bahwa kesadaran masyarakat mampu memaksimalkan potensinya sendiri lebih ditentukan oleh kreatifitasnya di dalam kelompok dan bukan karena fasilitas yang diberikan oleh pemerintah. Karena itu, model kaji tindak terhadap kelompok yang demikian inilah yang perlu diperluas agar ke depan mereka mampu memberdayakan dirinya. Hasil penelitian menjelaskan bahwa masalah ketidakberdayaan masyarakat tidak selamanya disebabkan karena ketiadaan modal sekalipun modal tetap dipentingkan. Namun, lebih banyak dikarenakan kesadaran dan etos kerja yang belum terbangkitkan agar dapat ke luar

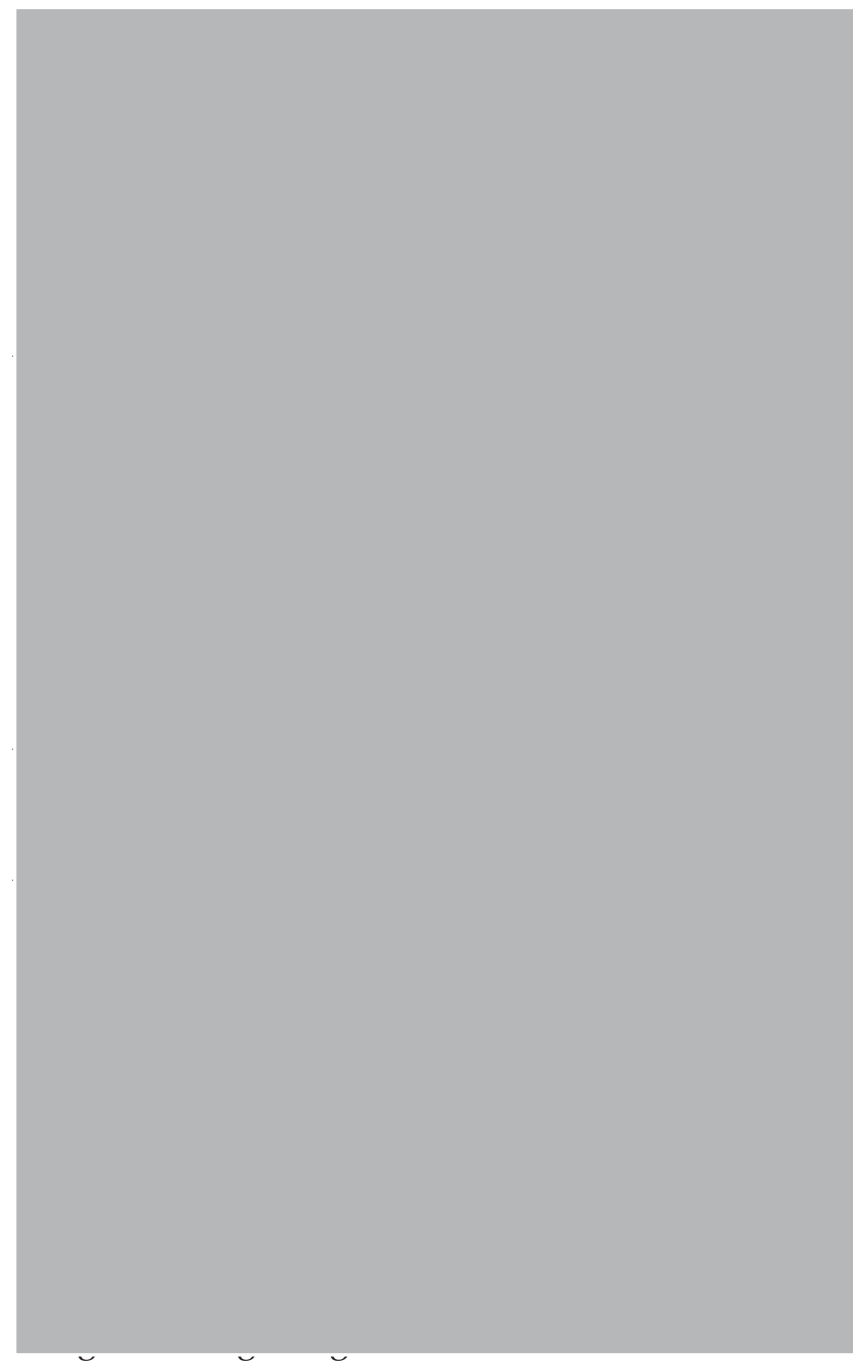




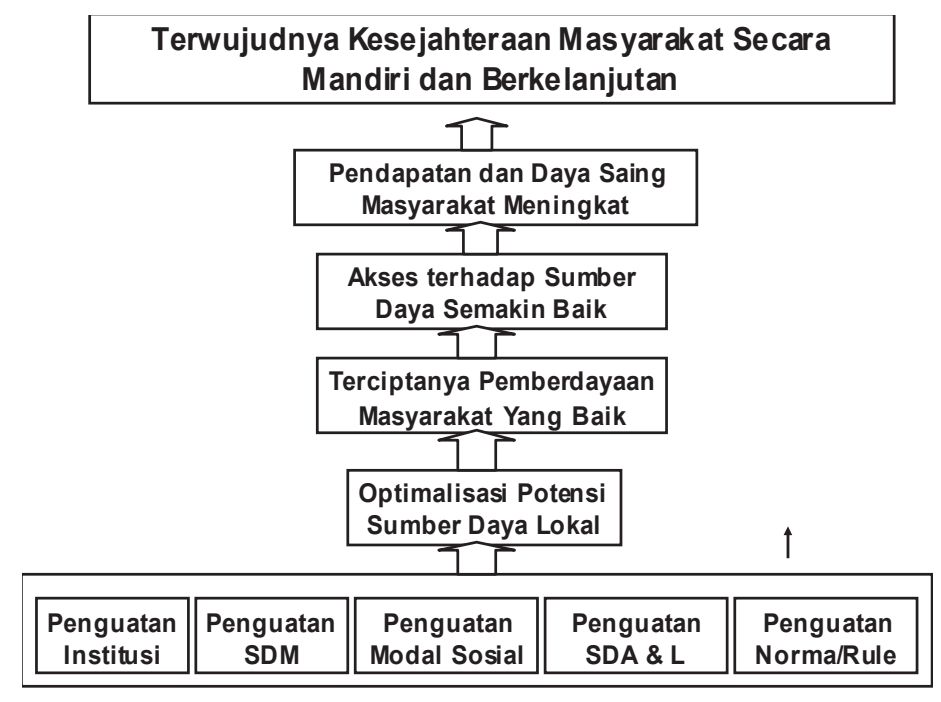

Gambar 7. Pohon Alternatif Penyelesaian Masalah

serta mendorong untuk mencapai keberlanjutan. Selain itu, cara untuk meningkatkan kesejahteraan yang berkelanjutan ini juga dapat digambarkan seperti pada Gambar 8.

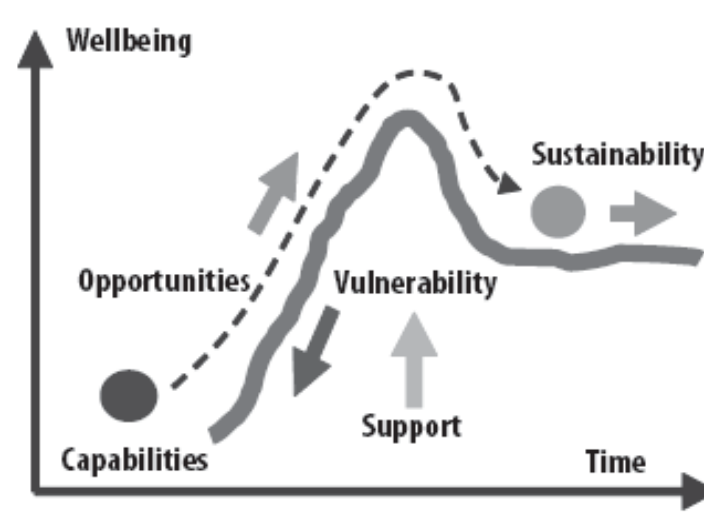

Gambar 8. Beberapa Prinsip Peningkatan Kesejahteraan Warga Miskin

Oleh karena itu, program pengentasan kemiskinan ini harus dipadukan antara program pemerintah pusat, pemerintah daerah dan peneliti ini serta LSM atau lembaga terkait lainnya. Dengan besarnya perhatian dan komitmen semua pihak terhadap pengentasan kemiskinan dan rawan pangan secara integral, maka partisipasi aktif masyarakat miskin sendiri juga semakin besar. Dengan demikian, dapat ditegaskan kembali bahwa kemiskinan paling tidak memiliki tiga dimensi utama yang harus segera ditangani yakni melalui; kebutuhan pokok, kebutuhan sosial, dan kebijakan pembangunan. Dengan kata lain, ketiga dimensi ini jauh lebih menarik secara eklusif daripada kita hanya terus berdebat tentang angka kemiskinan yang dihasilkan dari berbagai pendekatan yang berbeda misalkan antara pendekatan BPS dan pendekatan BKKBN.

\section{SIMPULAN}

Model kaji tindak community base economic development participation merupakan program yang penting untuk dikembangkan sebagai upaya pengentasan kemiskinan dan rawan pangan. Model ini mampu meningkatkan kesadaran warga masyarakat untuk lebih memaksimalkan potensinya sendiri melalui kreativitasnya dan bukan karena fasilitas yang diberikan oleh pemerintah setempat. Karena itu, model kaji tindak perluasan pembangunan melalui pemberdayaan kelompok warga miskin yang lebih berbasis pada potensi lokal dan kreativitas inilah yang perlu terus diperluas agar ke depan mereka mampu memberdayakan dirinya. Selanjutnya, melalui strategi pengembangan potensi kearifan lokal dan ekonomi produktif akan diperoleh berbagai keunggulan komparatif, sedangkan melalui strategi pengembangan kreativitas (ekonomi kreatif) akan diperoleh keunggulan kompetitif.

Dengan demikian, hasil penelitian ini me- 
negaskan bahwa masalah rawan pangan dan kemiskinan warga masyarakat tidak selamanya disebabkan karena ketiadaan modal sekalipun modal tetap saja diperlukankan. Namun, lebih dikarenakan kesadaran dan etos kerja yang terbangkitkan agar dapat keluar dari masalah kemiskinan dan rawan pangan.

Selanjutnya, direkomendasikan bahwa modal dasar pembangunan ke depan tidak hanya bertumpu pada dana atau modal, justru yang lebih penting adalah bertumpu pada potensi kualitas dan kuantitas sumber daya manusia (SDM) yang kreatif atau pembangunan manusia yang memiliki kepedulian sosial dan mental mandiri, baik mandiri secara individu, keluarga, kelompok maupun masyarakat. Penguatan warga miskin menjadi SDM yang mandiri dan memiliki kepedualian sosial inilah yang merupakan tantangan pembangunan ekonomi masyarakat di Indonesia pada saat sekarang dan masa datang agar mereka terlepas dari kondisi kemiskinan dan rawan pangan.

Ucapan terima kasih. Terima kasih kepada DP2M DIKTI yang telah memberikan dana dalam penelitian ini melalui Program Penelitian Hibah Kompetitif sesuai Perioritas Nasional Batch II 2009 No.335/SP2H/PP/DP2M/VI/2009.

\section{DAFTAR PUSTAKA}

BPS. 2008. Kecamatan Bringin Dalam Angka, Semarang: BPS Kabupaten Semarang

Komite Penanggulangan Kemiskinan Republik Indonesia. 2005. SNPK Strategi Nasional Penanggulangan Kemiskinan. Jakarta:KPK.

Kuncoro, Mudrajad. 2003. Ekonomi Pembangunan: Teori, Masalah dan Kebijakan. Edisi Ketiga, Yogyakarta: UPP AMP YKPN.

Listyaningsih, Umi. 2004. Dinamika Kemiskinan di Yogyakarta. Yogyakarta: Pusat Studi Kependudukan dan Kebijakan UGM, Partnership for Economic Growth, USAID.

Mujiyadi. B. dan Gunawan. 2000. Pemberdayaan Masyarakat Miskin (Suatu Kajian terhadap
Masyarakatdi Sekitar Kawasan Industri) dalam Informasi Vol. 5 No. 1 Januari 2000. Jakarta: Balitbang Depsos RI.

Prasetyo, P. Eko, 2008, The Quality of Growth: Peran Teknologi dan Investasi Human Capital sebagai Pemacu Pertumbuhan Ekonomi Berkualitas, Jurnal Ekonomi dan Kebijakan, Vol. 1 No. 1 September 2008. Semarang: Jurusan EP FE UNNES.

Prasetyo, P. Eko, dan Siti Maisaroh. 2009a. Model Strategi Pemberdayaan Ekonomi Rakyat Sebagai Upaya Pengentasan Kemiskinan, Jurnal Ekonomi Trikonomika, Terkareditasi Nasional, Volume 8, No. 2, Desember 2009. Bandung: FE Unpas.

Prasetyo, P. Eko, Marimin dan Adang S. 2009b. Model Kaji Tindak Perluasan Program Pembangunan Berbasis Masyarakat Sebagai Upaya Pengentasan Kemiskinan dan Rawan Pangan, Laporan Penelitian Hibah Kompetitif Sesuai Prioritas Nasional, DP2M, Jakarta: Dirjen Dikti.

Sisparyadi. 2005. Desa Rawan Pangan dan Program Raskin, Warta Pedesaan PSPK UGM, No. 05/XXIII/ Mei 2005, Yogyakarta: PSKK UGM.

Smeru. 2002. The SMERU: Research Institute, No. 02 April-Juni, 2002

Smeru. 2004. Strategi Penanggulangan Kemiskinan Nasional Laporan Penelitian, Lembaga Penelitian SMERU. Jakarta: Bappenas

Suharto, Edi. 2003. Kemiskinan dan Keberfungsian Sosial, Studi Kasus Rumah Tangga Miskin di Indonesia. STKS Bandung Press

Suyono, Haryono. 2008. Merangsang Pengentasan Kemiskinan Model MDGs, Gemari, Edisi 93/tahun IX/Oktober, 2008.

World Bank. 2002. A Sourcebook for Poverty Reduction Strategies. Washington: World Bank. 